\title{
The Tie That Binds: Some Thoughts About the Rule of Law, Law and Economics, Collective Action Theory, Reciprocity, and Heisenberg's Uncertainty Principle
}

\author{
Richard E. Levy"
}

\section{INTRODUCTION}

I am deeply grateful and honored to have been selected as the first holder of the J.B. Smith Distinguished Professorship in Constitutional Law and pleased to offer this inaugural lecture. James Barclay Smith was and remains a legendary figure at the University of Kansas-famous for his penetrating intellect, his witty sayings, and his devotion to the forms of civility. ${ }^{1}$ I can only hope one day to be described, as J.B. Smith has been, as a "great constitutionalist."

An inaugural lecture presents a unique challenge and a unique opportunity. The challenge is to say something profound that befits the high honor of the occasion, while keeping it accessible and interesting to a diverse audience that includes family and friends, faculty from various disciplines throughout the university, and colleagues from the law school. The opportunity is to say whatever you want to a captive audience. I decided not to worry about saying anything profound or accessible and indulge in the opportunity to say what I want to a captive audience.

J.B. Smith Distinguished Professor of Constitutional Law, University of Kansas School of Law. I would like to thank Rob Glicksman, Peter Schanck, Elinor Schroeder, and many other colleagues for their helpful comments and Ben Zimmerman, class of 2008, for valuable research assistance.

1. I was particularly taken with the saying, as reported to me by Mike Davis, that "just because the kittens are born in the oven doesn't make them biscuits." The truth of this statement is, I think, incontrovertible, even if the meaning is not. For further discussion of J.B. Smith's career at the University of Kansas School of Law, see Charles H. Oldfather, In Memoriam, James Barclay Smith, 27 U. KAN L. REV., at xi (1978); Paul E. Wilson, James Barclay Smith, 1979 AALS ProC. 191 (1979).

2. M.H. Hoeflich \& Lawrence Jenab, The Origins of the Kansas Law Review, 50 U. KAN. L. REV. 375, 380 (2002). Smith was the author of a book, Studies in the Adequacy of the Constitution (1939), and twenty-nine articles, published in prominent journals such as the California Law Review, the Virginia Law Review, the Georgetown Law Journal, and the University of Chicago Law Review. 
This lecture brings together a variety of little ideas I have had over the years that seem to me important and connected, yet do not lend themselves to the usual forms of legal scholarship. In some ways the ideas are disparate and you may wonder as I proceed whether they belong together at all. I assure you, I do have a point that brings all these ideas together, at least in my own mind.

\section{THE RULE OF LAW}

The first topic I want to discuss is the rule of law. This concept, perhaps most famously captured in the phrase "a government of laws and not of men," 3 speaks to the rule of law as an essential prerequisite for constitutional government. The rule of law as I use that term here is embodied in the essential idea that the law is binding. As applied to constitutional law, it means that governmental authority must have a basis in law and that the actions of government and government officials are subject to the law and constrained by it. ${ }^{4}$ The rule of law is a mysterious force. It has no material substance and cannot be measured or quantified, yet it is remarkably powerful.

Consider as an example the aftermath of the Supreme Court's decision in Bush v. Gore, ${ }^{5}$ which prompted Al Gore immediately to concede the election, explaining that "while I strongly disagree with the Court's decision, I accept it. I accept the finality of this outcome which will be ratified next Monday in the Electoral College."6 Why would Al Gore, the apparent successor to a sitting President, winner of the popular vote, and second in command of the most powerful armed forces in the world, concede the presidency on the basis of a decision of nine individuals (actually only five of them), who have no army at their command (and no superhuman powers)?

3. Although the phrase is often quoted from Chief Justice Marshall's opinion in Marbury v. Madison, 5 U.S. (1 Cranch) 137, 163 (1803), it appears earlier in the works of John Adams. See JoHn ADAMS, Novanglus Papers No. 7, in 4 THE WORKS OF JOHN ADAMS 106 (Charles Francis Adams ed., Boston, Little, Brown, \& Co. 1851) (1774) ("If Aristotle, Livy, and Harrington knew what a republic was, the British constitution is much more like a republic than an empire. They define a republic to be a government of laws, and not of men."). It also appears in the Massachusetts Constitution. See MASS. CONST. pt. I, art. XXX.

4. The classic statement of the rule of law is by A.V. Dicey. See A.V. DiceY, InTroduction TO THE STUDY OF THE LAW OF THE CONSTITUTION 120-21 (Liberty Classics 1982) (1885). For general discussion of the possible uses and meanings of the concept of the rule of law, see Richard H. Fallon Jr., "The Rule of Law" as a Concept in Constitutional Discourse, 97 COLUM. L. REv. 1 (1997).

5. 531 U.S. 98 (2000).

6. Vice President Al Gore, Speech Conceding the Election to George W. Bush (Dec. 13, 2000), transcribed in N.Y. TimES, Dec. 14, 2000, at A26. 
The answer is the rule of law. We accept the supremacy of law and the authority of the Supreme Court's pronouncements of it. Thus, Al Gore accepted the decision because he considered himself bound by the law. Even if Gore might have been tempted to defy the Court, he surely recognized that such a course of action would have provoked massive public outrage because the public accepts the Supreme Court's decisions as authoritative statements of law, so that defiance of the Court would be viewed as defiance of the rule of law.

In some other countries, the rule of law is less firmly established and less powerful. ${ }^{7}$ A comparison among countries suggests that the rule of law is closely correlated with the well being of citizens. In countries committed to the rule of law, citizens fare better economically, live safer and more secure lives, and enjoy greater civil and political liberties. ${ }^{8}$ In countries without it, citizens struggle on many fronts. Of course, it is difficult to say what is cause and what is effect; but I think it reasonably clear that the rule of law tends to promote these desirable conditions, even if it may also be true that these conditions tend to strengthen the rule of law.

The foregoing observations raise some very interesting questions. What is the source of the rule of law's ability to control the exercise of power? How can the rule of law be developed and maintained? Experience around the world suggests that without the rule of law, it is nearly impossible to develop effective constitutional democracies. But there is no established formula for developing the rule of law in societies and governments where it does not exist.

These observations also suggest two critical conclusions. First, we in the United States are immensely fortunate to have a society in which the government is predicated on the rule of law and in which the rule of law operates to constrain powerful government and private actors-even if it does not always function perfectly. Second, the legal profession has a special obligation to respect, preserve, and nurture the rule of law, especially because once the rule of law is lost, it is not clear how it can be regained.

7. Consider, for example, recent challenges to the rule of law in Pakistan. See William H. Neukom, President, American Bar Association, Op-Ed: Standing Up for Rule of Law in Pakistan (Nov. 14, 2007), available at http://www.abanet.org/abanet/media/oped/oped.cfm?releaseid=219.

8. See generally Todd J. Zywicki, The Rule of Law, Freedom, and Prosperity, 10 SuP. CT. ECON. REV. 1 (2003). 


\section{LAW AND ECONOMICS}

The next topic I want to consider is the law and economics movement, which applies the tools of economics to analyze the law. My alma mater, the University of Chicago Law School, has long been at the forefront of this movement, and I had the good fortune to clerk for Judge Richard Posner, who is perhaps the most influential and significant theorist and advocate of the law and economics approach. ${ }^{9}$ Although law and economics claims to be primarily descriptive, it has important normative implications for the law.

Law and economics starts with the premise that individuals generally act as "rational profit maximizers"; that is, they will choose a course of conduct that (based on available information) maximizes their benefits and minimizes their costs. It follows from the law and economics perspective that people will not comply with the law if the costs of compliance are greater than the expected costs of noncompliance, which is usually expressed as the sanction for violation discounted by the probability of being caught. In the most straightforward terms, then, it makes sense to understand how the law affects the incentives of those subject to it and to design legal rules accordingly.

Law and economics is relatively unconcerned with why people consider some things to be benefits and others costs, or why they place higher values on some benefits (or avoiding some costs) than others. In this respect, it resembles Skinnerian behavioral psychology: ${ }^{10}$ both assume that people seek pleasure and avoid pain; both imply that human behavior can be influenced by constructing proper incentives; and both take people's preferences (what economists call their "utility function") as a given. From the law and economics perspective, incentives based on material and physical well being are fairly easy to account for, but other values are not.

The law and economics perspective identifies some important truths and is a powerful tool for thinking about the law and legal issues. But it is also incomplete and has difficulty accounting for much of human behavior. For example, a central foundation of law and economics is the Coase Theorem, according to which (in the absence of transaction costs and wealth differentials) a property right will end up with the user who

9. See generally RichARD A. POSNER, ECONOMIC ANALYSIS OF LAW (7th ed. 2007).

10. See generally B.F. SKINNER, WALDEN TWO (1948) (developing fictionalized account of a utopian society based on behaviorist principles). Interestingly, both also often provoke vigorous and emotional criticisms for their mechanistic view of human behavior and for their political implications. 
values it most, regardless of its initial allocation, because the user who values it most will be willing to buy it from the original holder. ${ }^{11}$ In order for this theorem to work, people's maximum offer price (what they would pay to acquire a right) must be the same as their minimum asking price (what they would accept to sell the right). While this equivalence seems intuitively plausible, it turns out that it does not actually reflect human behavior. Social science literature makes clear that there is an "endowment effect": people's offer price is typically less than their asking price. ${ }^{12}$

If such a central premise of economic analysis is inconsistent with human behavior, then we might also question its other assumptions, including the central premise that individuals are rational profit maximizers. Consider something as basic and universal as the family. As a husband and father, I spend much of my income (and the material well-being it can purchase) not on my own behalf, but rather in the interests of my family. Is that rational profit maximization?

From an economic perspective, this only makes sense if I get something I value more than money and material well being from my family. But what exactly do I get and why do I value it enough to make material sacrifices? Law and economics does not have a ready answer. It does not attempt to explain why people value what they value, or when and how non-material incentives will affect individual behavior. ${ }^{13}$ It does not help us understand why the vast majority of parents care for their children, or why some do not. And it offers little insight as to why anyone would, for example, risk his or her life for a complete stranger with little or no expectation of reward. ${ }^{14}$

Yet non-material and other-regarding values are a central force in human behavior. Each of us develops moral or ethical values that factor into our decision-making. Societies shape these values, which are essential for people to live together. To be sure, different people have different value systems and attach greater or lesser weight to their values. Nonetheless, values are a central component of individual action. When

11. See R.H. Coase, The Problem of Social Cost, 3 J.L. \& ECON. 1 (1960).

12. See, e.g., Daniel Kahneman, et al., Experimental Tests of the Endowment Effect and the Coase Theorem, in BeHAVIORAL LAW AND ECONOMICS 211 (Cass R. Sunstein ed., 2000) (discussing the endowment effect and offering empirical support for it).

13. There is, however, some recent scholarship attempting economic analyses of moral and other values. See, e.g., Louis Kaplow \& Steven Shavell, Moral Rules, the Moral Sentiments, and Behavior: Toward a Theory of an Optimal Moral System, 115 J. POL. ECON. 494 (2007).

14. Consider in this regard the man who risked his own life to save another man who fell onto the subway tracks in New York City. See Deepti Hajela, Man Who Fell on NYC Subway Tracks Saved, WASH. POST, Jan. 2, 2007, http://www.washingtonpost.com/wp-dyn/content/article/2007/ 01/02/AR2007010200835.html. 
we do the "right thing," we feel good; when we do something we know or believe is wrong, we suffer from a guilty conscience. These benefits and costs are no less real just because they are difficult to observe or measure.

Bringing this discussion back to the rule of law, the key point is that respect for the rule of law is an important social value that affects individual behavior in society. Put differently, the idea that law is "binding" reflects a broadly accepted moral obligation to obey it. The guilt associated with violating this moral obligation is an additional cost to violating the law beyond the expected costs of punishment. The calculus of law and economics has a hard time accounting for the moral value of complying with the law or the psychic costs of violation.

\section{COLLECTIVE ACTION}

The next concept I want to discuss is the application of economic principles to government and political activity, particularly in relation to the dynamics of collective behavior. Like law and economics generally, collective action theory is an invaluable tool and I have used it extensively in my work on federalism. Also like law and economics, collective action theory has its limitations.

As developed in Mancur Olson's influential work, The Logic of Collective Action, ${ }^{15}$ the benefits of collective behavior are often a collective or public good. The essential characteristics of a collective or public good are that, once it is produced, (1) consumption of the good by one person does not diminish the ability of others to consume it as well; and (2) there is no way for the producer to limit consumption so as to charge a price for the good. A lighthouse is a simple example of a public good: its warning is not diminished no matter how many vessels see it and the warning cannot be limited only to ships who pay for it. Law and economics predicts that when collective goods are involved, members of a collective have incentives to "free ride" on the efforts of others: that is, to wait for others to build the lighthouse and get the benefit of its warning without bearing the cost.

The free-rider problem creates a so-called "prisoners' dilemma" situation, named for the example commonly used by game theorists to illustrate the problem. Assume two prisoners who have jointly committed a crime and who must negotiate with prosecutors for the

15. Mancur Olson, The Logic of Collective Action: Public Goods and the Theory OF GROUPS (1971). 
lowest possible sentence. The sentence each receives depends on whether he confesses and implicates the other or remains silent, and on whether the other confesses and implicates him or remains silent. As any Law \& Order aficionado knows, you get a better deal if you implicate your partner and you get a raw deal if your partner implicates you. For either prisoner, the result is better if he implicates his partner regardless of what the partner does. When the other remains silent, he will get six months if he confesses and one year if he remains silent. When the other confesses, he will get two years if he also confesses and five years if he remains silent. For each prisoner, the best strategy is to confess regardless of what the other does, with the result being a total sentence of four years (two each). Viewed from the perspective of the prisoners both individually and as a collective, however, the best outcome occurs when both remain silent, which would result in a total sentence of two years (one year each). In the same way, when collective action would produce a public or collective good, the best outcome for the collective may be subverted by the incentives for members to free ride.

The prisoners' dilemma can be overcome if the members of the collective can reach and follow an agreement to act collectively. There are, however, transaction costs associated with doing so, related both to the negotiation of the agreement and the enforcement of it. In the example of the prisoners, if they are in separate cells, they cannot negotiate; if they agree in advance to remain silent, neither can be sure that the other will stick to the agreement. Olson observed that, as a collective becomes larger, the transaction costs of reaching and enforcing agreements increase dramatically. There are more members to find, negotiate with, and monitor; and each member has less at stake and stronger incentives to free ride. ${ }^{16}$

All of this has important implications for thinking about constitutional government. Functionally, government is a mechanism to facilitate collective action by a very large collective that would otherwise be unable to reach and enforce agreements to pursue collective goods. In a representative democracy, the transaction costs of negotiating and reaching agreements are overcome by empowering legislatures to make collective decisions on behalf of millions of people through majority vote

16. Id. at 46-48. For this reason, many "public choice" theorists posit that concentrated interest groups have organizational advantages in the political system that facilitate the pursuit of legislation creating monopoly "rents" by restricting competition or conferring competitive advantages ("rent seeking" behavior). See generally DANIEL A. FARBER \& PhiliP P. Frickey, LAW AND PUblic CHOICE: A CRITICAL INTRODUCTION (1991) (providing a general introduction to public choice theory and criticisms of it). 
without the need for individual consent. To reduce the costs of enforcing such agreements, they are expressed in terms of laws. The rule of law represents a societal commitment to accept and comply with these collective decisions that greatly reduces the costs of monitoring and enforcing the collective agreement. While there is a legal system empowered to use coercive sanctions to enforce the law if necessary, without the rule of law the system would collapse under the weight of enforcement costs.

Collective action theory captures an important dynamic, but it suffers from some of the same problems as law and economics generally. If we follow the theory to its logical conclusion, it is hard to see why any collective action involving large numbers could ever succeed. Yet even without the rule of law and the coercive enforcement authority of the legal system, collective action is all around us and succeeds with remarkable frequency, given the incentives for free riding that Olson describes. Law and economics and collective action theory have difficulty explaining why. It is suggested, for example, that members must be receiving some other benefit beside the collective good, such as "solidarity" benefits that come from participating in a group, but this tells us little about why people might value group participation and does not help us understand when such values will overcome incentives to free ride.

\section{RECIPROCITY}

Recent social science literature suggests another dynamic may be at work here: reciprocity. The self-centered impulses to maximize one's own welfare and to take advantage of others by free riding exist alongside a countervailing impulse to reciprocate. ${ }^{17}$ That is, when others act with an eye toward the collective good, we are more likely to do the same. At the same time, though, if others are free riding, we are more likely to do the same.

I think this dynamic is something most of us have experienced in our own lives. I have a vivid recollection of cleaning up a rather large mess after an event with a high school youth group. At the beginning most of us pitched in and worked collectively, but a few did not. As time went on, people who were working noticed that some were not and a few joined those free riders, followed soon by others. As more and more

17. See generally Dan M. Kahan, The Logic of Reciprocity: Trust, Collective Action, and Law, 102 MiCH. L. REV. 71 (2003). 
people stopped cleaning, a tipping point was reached and the work came to a complete standstill. We have all participated in groups in which a cooperative spirit pervades, all or most members contribute voluntarily to the success of the collective endeavor, and the group prospers. We have also been in groups that fail because too many members free ride on the efforts of others. More fundamentally, we see that members of the group take their cues from what other members are doing.

Law and economics and collective action theory have difficulty fully explaining reciprocal behavior. It is true that reciprocity is a sound longterm strategy for repeat players in a prisoners' dilemma collective game: over the long term, cooperating with other cooperative players (remaining silent) while pursuing an individual strategy with others who do not (cutting a deal) will maximize individual gains while minimizing individual losses.

But it seems to me that reciprocal cooperative behavior is more than just a sound economic strategy-it is part and parcel of who we are. People value belonging. Just as they are instinctively rational profit maximizers, so too are they instinctively social and cooperative. These instincts are often in tension with each other and each individual will balance the competing impulses differently in different situations.

To a certain extent, the degree to which we tend to act individualistically or cooperatively may be hard-wired into each of us, but it is clear that individual experience affects those tendencies as well. Among other things, the society in which we live helps to shape our values. Most societies-some more so than others-have a powerful norm of reciprocity and treat free riding as immoral behavior. ${ }^{18}$

Reciprocity suggests that collective action is more likely to be successful when members of the collective have confidence that other members will contribute to the collective effort, and less likely to be successful if members believe that others will free ride. It follows that successful collectives have some "bonding mechanism": that is, a means of assuring members that others are acting collectively. In the context of the large collective known as the "state," that bonding mechanism is the rule of law. The rule of law is critical for the success of government precisely because it is a deeply ingrained value that causes compliance with the law even when a rational profit maximizer might conclude that expected gain from breaking it outweighs the expected costs.

18. See, e.g., Robert Sugden, Reciprocity: The Supply of Public Goods Through Voluntary Contributions, 94 ECON. J. 772, 772 (1984) (advancing the theory that voluntary production of public goods is successful because "most people believe free riding to be morally wrong"). 


\section{HEISENBERG's UNCERTAINTY PRINCIPLE}

The last idea I want to talk about is the Uncertainty Principle, which comes to us from the field of quantum physics. In proposing the Uncertainty Principle, Werner Heisenberg argued that it is impossible to know both the position and momentum of an electron at any given point in time because the very act of observing its position (with light of a sufficiently short wavelength) causes the electron to be struck by at least one photon and changes its momentum. The physics of this principle is beyond me, but Heisenberg's argument is a powerful metaphor for the "observer effect," which applies more universally. Observing a teacher in the classroom affects the dynamics of the class; news reporting on political contests affects the outcomes of elections; and legal scholarship affects the law.

This last example is what brings together the disparate topics I have discussed today. Legal scholarship influences not only the content of the law, but also the way the legal profession and ultimately society as a whole think about the law. This includes attitudes toward the rule of law itself. My concern over the years has been that, while law and economics and collective action theory are powerful and important tools for understanding the law, they may have a detrimental impact on the rule of law.

Let me offer a concrete illustration. Some years ago a prominent scholar came to the law school and delivered a paper on "customary" international law. International law in general is different from domestic law because there is no sovereign government with the authority to make and enforce rules; indeed, its very status as law has been forcefully challenged. Customary international law is analogous to the earliest forms of law in the sense that it emerges from consistent practices over time that come to be regarded as legally binding. The thesis of the paper was that there is really no such thing as customary international law because countries only follow it when it is in their self-interest to do so. ${ }^{19}$

Assuming that this thesis is true, the problem is that by saying so we alter the balance of self-interest by making it less costly to violate those practices. In the absence of a body with enforcement authority, the expected costs of punishment for violating customary international law are low. Thus, respect for the rule of law at an international level is

19. Jack L. Goldsmith \& Eric A. Posner, A Theory of Customary International Law, 66 U. CHI. L. REV. 1113, 1113 (1999) ("States do not comply with norms of CIL because of a sense of moral or legal obligation; rather, their compliance and the norms themselves emerge from the states' pursuit of self-interested policies on the international stage."). 
essential to making the international legal system work and provide the foundation for international cooperation in various matters. When prominent legal scholars challenge the force of the rule of law in international relations, it tends to reduce the value of the rule of law and thus reduce costs of violating the law.

By stressing individualistic behavior and the material (and measurable) costs and benefits of individual action, many proponents of law and economics undermine reciprocity in general and the rule of law in particular. ${ }^{20}$ Indeed, there is a fascinating literature addressing the observation that economists are generally less cooperative than others and suggesting that training in economics may play a causative role. ${ }^{21}$ By the same token, the more often people hear the message that obedience to the law makes sense only when it is in their own selfinterest to do so, the less likely they are to obey the law just because it is the law and the less likely they are to believe that others will do the same. Over time, more and more people may become free riders and, in a worst-case scenario, the tipping point is reached and the rule of law is lost as a bonding mechanism for collective action.

In the United States, we are a long way from that point at the present time. But if we value the benefits of the rule of law-security, prosperity, and liberty — we must nurture and reinforce the rule of law as a social value.

\section{VII.CONCLUSION}

I am not entirely sure what the full implications of these observations are. I certainly do not mean to suggest that there is anything improper or morally wrong in engaging in scholarship with a law and economics or

20. Thus, for example, Richard Posner has argued that traditional legal concepts such as justice, equality, or the rule of law are empty concepts and that judges should focus on an empirical pragmatism that maximizes social utility. See Richard A. Posner, THE Problems of JURISPRUDENCE 454-69 (1990). In response, Stanley Fish has observed that the public values traditional legal concepts as a basis for judicial decision. See Stanley Fish, Almost Pragmatism: Richard Posner's Jurisprudence, 57 U. CHI. L. REV. 1447, 1462 (1990). For a useful summary of the Posner-Fish debate, see Peter C. Schanck, Understanding Postmodern Thought and Its Implications for Statutory Interpretation, 65 S. CAL. L. REV. 2505, 2566-69 (1992).

21. See Robert H. Frank, Thomas Gilovich \& Dennis T. Regan, Does Studying Economics Inhibit Cooperation?, in JUDGMENT AND DECISION MAKING: AN INTERDISCIPLINARY READER 183, 190 (Terry Connolly, Hal R. Arkes \& Kenneth R. Hammond eds., 2d ed. 1999) (concluding that comparative data regarding cooperative behavior in underclassmen and upperclassmen are "at least consistent with the hypothesis that training in economics plays some causal role in the lower observed cooperation rates of economists"). 
collective action perspective. I would be condemning much of my own work.

I do believe, however, that we in the legal academy must recognize that, despite its amazing power, the rule of law is also a fragile thing. In our teaching, in our scholarship, and in our interactions with the public, we can do much to reinforce the rule of law as a social value. We owe it to the collective to do so. 